\title{
Quantitative sacroiliac scintiscanning: a sensitive and objective method for assessing efficacy of nonsteroidal, anti-inflammatory drugs in patients with sacroiliitis
}

\author{
N. A. DUNN, B. H. MAHIDA, M. V. MERRICK, AND G. NUKI
}

From the Rheumatic Diseases Unit and Division of Nuclear Medicine, Department of Medicine (WGH), University of Edinburgh

SUMMARY Serial computer assisted quantitative sacroiliac scintiscanning (SI joint/sacrum ratios) 3 hours after low dosage $(5 \mathrm{mCi}){ }^{99 \mathrm{~m}} \mathrm{Tc}$ methylene diphosphonate has been used as an objective index of sacroiliitis in a single blind 14-day cross-over comparison of azapropazone $600 \mathrm{mg}$ b.d. and naproxen $500 \mathrm{mg}$ b.d. in 18 patients with active sacroiliitis. Clinical assessments included visual analogue scales for measurement of pain and early morning stiffness, chest expansion, a modified Schober test, and goniometric measurement of thoracolumbar spinal flexion by means of an inclinometer. Statistically significant decreases in pain $(p<0.001)$ and early morning stiffness $(p<0.001)$ followed treatment with each NSAID, but there was no significant difference in the fall in these parameters, although 15 out of 18 patients expressed a preference for naproxen. Chest expansion and thoracolumbar flexion were not significantly affected by either drug. Serial quantitative scintigraphy showed a mean fall in joint sacrum ratios following each treatment which was statistically significant $(p<0.02)$ only after naproxen. Serial quantitative scintigraphy can be used as an objective method of assessing sacroiliitis and was sufficiently sensitive to reflect the patients' subjective preference in a short-term comparison of 2 NSAID.

The sensitivity of sacroiliac (SI) scintigraphy as an objective measure of sacroiliitis has been greatly increased by computer quantification of the uptake of tracers of bone seeking isotopes over the SI joints compared with that over the sacrum. ${ }^{1}$ The technique has been shown to be particularly sensitive in early sacroiliitis, ${ }^{2}$ but uptake is more variable in patients with advanced disease and established radiological changes. ${ }^{34}$

Treatment with nonsteroidal anti-inflammatory drugs (NSAID) can lower the SI joint/sacrum scan ratio (SI/S ratio), ${ }^{5}$ and this may be partly responsible for the considerable overlap of SI/S ratios in normal subjects and patients with sacroiliitis found by some investigators. ${ }^{67}$

Following early suggestions $\mathrm{s}^{58}$ that serial quantitative SI scintigraphy (SQSS) might be useful in assessing the short-term efficacy of NSAID in the treat-

Accepted for publication 8 March 1983.

Correspondence to Professor G. Nuki, Rheumatic Diseases Unit, University of Edinburgh, Northern General Hospital, Ferry Road, Edinburgh EH5 2DQ. ment of inflammatory sacroiliitis we have used it as a method of objective assessment in a short-term cross-over trial of 2 NSAID in a group of patients with active sacroiliitis. The results have been compared with those of conventional methods of clinical assessment.

\section{Patients and methods}

TRIAL DESIGN

The study was a single-blind, cross-over comparison of the effect of 14 days' treatment with azapropazone $600 \mathrm{mg}$ b.d. and naproxen $500 \mathrm{mg}$ b.d.in patients with active sacroiliitis. Eighteen patients (16 male, 2 female) with clinically active sacroiliitis who all satisfied the New York criteria for definite ankylosing spondylitis ${ }^{9}$ were randomly allocated into 2 groups, $A$ and B. After a 7-day drug-free washout period group A were treated with azapropazone $600 \mathrm{mg}$ b.d. and group B with naproxen $500 \mathrm{mg}$ b.d. for 14 days. After a further 7-day drug-free washout period group A patients received naproxen $500 \mathrm{mg}$ b.d. and group B patients azapropazone $600 \mathrm{mg}$ b.d. for 14 days. No 
other NSAID were allowed during the course of the study, but patients were given a supply of paracetamol as a rescue analgesic. Excluded from the trial were pregnant women or women likely to become pregnant, patients with peptic ulcers, bowel, renal, or hepatic disease, patients with blood dyscrasia and those receiving anticoagulant therapy, as well as all patients over the age of 65 years.

\section{A S S ESS MENTS}

Clinical assessments and QSS were undertaken at the beginning and end of each treatment period on days $7,21,28$, and 42 . Global pain and early morning stiffness were assessed on vertical $10 \mathrm{~cm}$ visual analogue scales. $^{10}$ Chest expansion $(\mathrm{cm})$ was measured at the 4th intercostal space. ${ }^{11}$ Flexion of the thoracolumbar spine was measured by McCrea and Wright's modification of the Schober test ${ }^{12}$ and by goniometric measurement with the improved inclinometer. ${ }^{13}$

Radiographs of the sacroiliac joints were graded for sacroiliitis prior to the start of the trial on a 4-point scale: (1) normal, (2) suspicious, (3) definite, (4) sclerosis/fusion.

At the end of the 6-week trial patients were asked to express any preference for either treatment and a record was made of any adverse side effects.

\section{QUANTITATIVE SACROILIAC SCINTIGRAPHY}

$5 \mathrm{mCi}(200 \mathrm{MBq})$ of ${ }^{99 \mathrm{~m}} \mathrm{Tc}$-methylene diphosphate were injected intravenously and the patient imaged 3 hours after the dose with a small-field Ohio Nuclear series Sigma 100 gamma camera fitted with specially designed extra high sensitivity collimator (giving approximately 4 times the sensitivity of the standard collimator). A total of 500000 counts were accumulated with the gamma camera centred on the body of the 1 st sacral vertebra.

Computer drawn isocount contours of $65 \%$ outlined the whole of each sacroiliac joint area. The sacral reference area comprised the bodies of the first 3 sacral vertebrae. Within each area of interest the total number of counts and area were calculated by the computer, the result being expressed in a ratio (the SI/S ratio) derived from the expression

$$
\mathrm{SI} / \mathrm{S} \text { ratio }=\frac{\text { mean SI counts } / \text { pixel }}{\text { mean sacral counts } / \text { pixel }}
$$

As there was no significant difference between left and right $\mathrm{Sl} / \mathrm{S}$ ratios in any of the subjects, a single SI/S ratio for each scan could be derived from the mean of the left and right SI/S ratios. By calculating the SI/S ratio in this manner errors arising from variability of tracer uptake throughout the SI joint are eliminated.

Statistical analyses were performed by Student's paired $t$ test.

\section{Results}

Groups A and B were well matched for age, sex, and disease activity (Table 1).

Global pain and early morning stiffness decreased significantly following treatment with both azapropazone and naproxen (Fig. 1), but there was no significant difference in the fall in these parameters following either drug. Fifteen out of 18 patients, however, expressed a definite preference for naproxen. Chest expansion and thoracolumbar flexion were not significantly affected by either drug (Table 2 ).

Serial measurements of QSS showed a mean fall in the SI/S ratio following treatment with both azapropazone and naproxen, by the fall was statistically significant only after treatment with naproxen (Fig. 2). This was true whether the drug was given first or

Table 1 Age, sex, and disease activity in the patients studied

\begin{tabular}{|c|c|c|}
\hline & Group A & Group B \\
\hline \multirow{5}{*}{$\begin{array}{l}\text { Number } \\
\text { Sex } \\
\text { Age, mean (range) years } \\
\text { Pain, VAS mean }( \pm S D), \mathrm{cm} \\
\text { EMS VAS, mean }( \pm S D), \mathrm{cm} \\
\text { Chest expansion, mean }( \pm \text { SD), } \\
\text { cm } \\
\text { Schober test, mean ( } \pm \text { SD), }\end{array}$} & 9 & 9 \\
\hline & $8 \mathrm{M} 1 \mathrm{~F}$ & $8 \mathrm{M} 1 \mathrm{~F}$ \\
\hline & $33(25-44)$ & $34 \cdot 5(21-46)$ \\
\hline & $\begin{array}{l}5 \cdot 3( \pm 1 \cdot 6) \\
5 \cdot 3( \pm 1 \cdot 3)\end{array}$ & $\begin{array}{l}5 \cdot 2( \pm 2 \cdot 1) \\
5 \cdot 1( \pm 2 \cdot 6)\end{array}$ \\
\hline & $4 \cdot 4( \pm 1 \cdot 0)$ & $4 \cdot 3( \pm 1 \cdot 0)$ \\
\hline $\begin{array}{l}\text { cm } \\
\text { Inclinometer, mean }\end{array}$ & $4 \cdot 8( \pm 0 \cdot 4)$ & $4 \cdot 7( \pm 0 \cdot 6)$ \\
\hline $\begin{array}{l}\text { Inclinometer, mean } \\
\quad( \pm \text { SD), degrees }\end{array}$ & $96 \cdot 4( \pm 4 \cdot 5)$ & $97 \cdot 5( \pm 4 \cdot 0)$ \\
\hline \multicolumn{3}{|l|}{ Radiological sacroiliitis } \\
\hline (grades) 1 & 7 & 8 \\
\hline 2 & 1 & 1 \\
\hline 3 & 0 & 1 \\
\hline 4 & 0 & 0 \\
\hline SI/S ratio, mean ( $\pm \mathrm{SD})$ & $1 \cdot 70( \pm 0 \cdot 1)$ & $1 \cdot 68( \pm 0 \cdot 1)$ \\
\hline
\end{tabular}

VAS = visual analogue scale. EMS = early morning stiffness

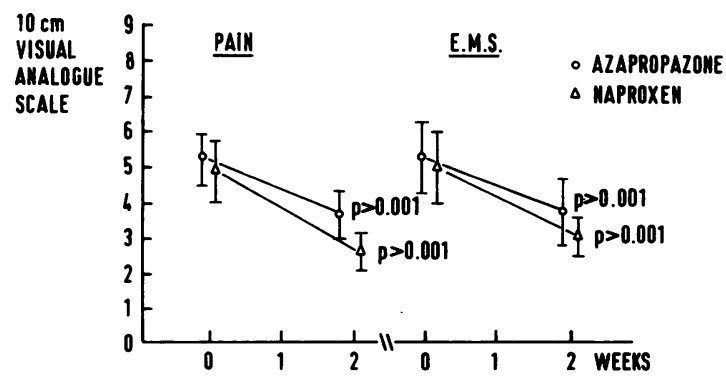

Fig. 1 Changes (mean $\pm S D$ pain score and early morning stiffness following treatment with azapropazone $600 \mathrm{mg} \mathrm{b.d}$. and naproxen $500 \mathrm{mg}$ b.d. 
Table 2 Measurements of chest expansion and thoracolumbar flexion

\begin{tabular}{lrrr}
\hline & $\begin{array}{l}\text { Chest } \\
\text { expansion } \\
(\mathrm{cm}),\end{array}$ & $\begin{array}{l}\text { Schober } \\
\text { test }(\mathrm{cm}), \\
\text { mean } \pm S D\end{array}$ & $\begin{array}{l}\text { Inclinometer } \\
\text { (degrees), } \\
\text { mean } \pm S D\end{array}$ \\
\hline Before azapropazone & $44 \cdot 4 \pm 1 \cdot 0$ & $4 \cdot 8 \pm 0 \cdot 4$ & $96 \cdot 4 \pm 4 \cdot 5$ \\
After azapropazone & $4 \cdot 3 \pm 0.9$ & $4 \cdot 7 \pm 0 \cdot 5$ & $96 \cdot 7 \pm 4 \cdot 1$ \\
Before naproxen & $4 \cdot 3 \pm 0.9$ & $4 \cdot 7 \pm 0.6$ & $97 \cdot 5 \pm 4 \cdot 0$ \\
After naproxen & $4 \cdot 4 \pm 0.9$ & $4 \cdot 7 \pm 0.4$ & $97 \cdot 5 \pm 4 \cdot 1$
\end{tabular}

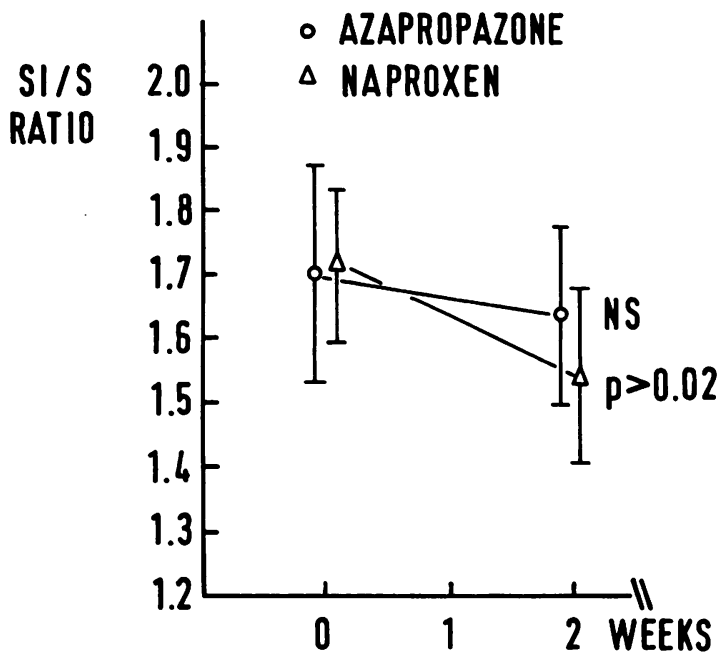

Fig. 2 Changes (mean $\pm S D$ ) SI/S ratio on repeat $Q S S$ following treatment with azapropozone $600 \mathrm{mg}$ b.d. and naproxen $500 \mathrm{mg}$ b.d.

second. The significant fall in QSS following naproxen appeared to reflect overall patient preference.

\section{Discussion}

Quantitative sacroiliac scintigraphy is now widely used as an aid to diagnosis in early sacroiliitis before the development of radiological changes, ${ }^{12}$ though there have been many reports of significant overlaps in SI/S ratios in normal subjects and patients with active sacroiliitis. ${ }^{36-814}$ False positive high values can also be obtained in subjects with osteoarthritis, rheumatoid arthritis, and metabolic bone diseases ${ }^{15}$ as well as normal subjects below the age of 20 years. It is clear from our studies as well as others ${ }^{58}$ that SI/S ratios can also be profoundly depressed by the administration of NSAID.

Moreover, the results of our study clearly show that with low doses of ${ }^{99 m} \mathrm{Tc}$-methylene diphosphate, a high-sensitivity collimator, and improved computer technology QSS can be used as a sensitive objective parameter to assess the short-term efficacy of NSAID. It is particularly interesting to note that QSS was sensitive enough to descriminate between 2 NSAID, accurately reflecting patient preference, while other subjective and objective clinical measurements were unable to do so. This is rather in contrast to QSS studies in patients with peripheral inflammatory arthritis, where scintigraphy has so far proved to be less sensitive than subjective measurements. ${ }^{16}{ }^{17}$

We are grateful to the Arthritis and Rheumatism Council for continuing financial support. Dr B. H. Mahida was supported by an A. J. Robins Clinical Research Fellowship.

\section{References}

1 Russell A S, Lentle B C, Percy J S. Investigation of sacroiliac disease: comparative evaluation of radiological and radionuclide techniques. J Rheumatol 1975; 2: 45-51.

2 Lentle B C, Russell A S, Percy J S, Jackson F I. The scintigraphic investigation of sacroiliac disease. J Nucl Med Allied Sci 1977; 18: 524-8.

3 Goldberg R P, Genant H K, Shimshak R, Shanes D. Applications and limitations of quantitative sacroiliac joint scintigraphy. Radiology 1978; 128: 683-6.

4 Zsanto E, Axellson B, Lindvall N. Detection of sacroiliitis: a comparison between profile scanning with the use of ${ }^{9 m} \mathrm{Tc}$ pertechnetate and scintigraphy with ${ }^{82 m} \mathrm{Tc}$ diphosphonate. $J$ Rheumatol 1977; 6: 129-36.

5 Namey T C, McIntyre J, Buse M, Le Roy E C. Nucleographic studies of axial spondarthritis. I. Quantitative sacroiliac scintigraphy in early HLA B27 associated sacroiliitis. Arthritis Rheum 1977; 20: 1058-64.

6 Berghs H, Reman J, Drieskens L, Kilbooms L, Polderman J. Diagnostic value of sacroiliac scintigraphy with ${ }^{88 m}$ technetium pyrophosphate in sacroiliitis Ann Rheum Dis 1978; 37: 190-4.

7 Dequeker J, Groderis T, Walraavens M, De Roo M, Evaluation of sacroiliitis: comparison of radiological and radionuclide techniques. Radiology 1978; 128: 687-9.

8 Esdail J M, Rosenthall L, Terkeltaub R, Kloiber R. Prospective evaluation of sacroiliac scintigraphy in chronic inflammatory back pain. Arthritis Rheum 1980; 23: 998-1003.

9 Bennett P, Wood P H N, (eds). Population studies of the rheumatic diseases. Proceedings of the 3rd International Symposium, New York, 1966. Amsterdam: Excerpta Medica, 1968; 456.

10 Dixon J S, Bird H A. Reproducibility along a $10 \mathrm{~cm}$ vertical visual analogue scale: Ann Rheum Dis 1981 40: 87-9.

11 Moll J H M, Wright V. Chest and spinal movement in ankylosing spondylitis Rheumatol Rehabil 1974; 13: 30-1.

12 McCrae I F, Wright V. Measurement of back movement. Ann Rheum Dis 1969; 28: 584-9.

13 Loebel W Y. Regional rotation of the spine. Rheumatol Rehabil 1973; 12: 233-4.

14 Snaith M L, Galvin S E, Short M D. The value of quantitative radioisotope scanning in the differential diagnosis of low back pain and sacroiliac disease. $J$ Rheumatol 1982; 9: 435-40.

15 Ho G, Sadovnikoff N, Malhotra C M, Claunch B C. Quantitative sacroiliac joint scintigraphy, a critical assessment. Arthritis Rheum 1979 22: 837-44.

16 Lee P, Dick W C. Assessment of disease activity and drug evaluation. In: Buchanan W W, Dick W C, eds. Recent advances in rheumatology I. Edinburgh: Churchill-Livingstone, 1976: 1-33.

17 Wallace D J, Buchanan M, Klinenberg J R. Joint scanning in rheumatoid arthritis: a literature survey. Semin Arthritis Rheum 1981; 10: 172-6. 